\title{
PARTNERSHIP
}

The Canadian Journal of Library and Information Practice and Research

Revue canadienne de la pratique et de la recherche en bibliothéconomie et sciences de linformation

vol. 16 , no. $2(2021)$

Features (editorially reviewed)

DOI: https://dx.doi.org/10.21083/partnership.v16i2.6440

CC BY-NC-ND 4.0

\section{The Canadian Index of Wellbeing: A Better Way to Assess and Communicate the Value of Libraries}

\section{Le "Canadian Index of Wellbeing »: une meilleure façon d'évaluer et de communiquer la valeur des bibliothèques}

\author{
Cara Bradley \\ Research \& Scholarship Librarian \\ University of Regina \\ cara.bradley@uregina.ca
}

\begin{abstract}
Résumé
Historically libraries have struggled to communicate their value in ways meaningful to both policy-makers and the general public. Traditional measures like collection and circulation counts, while useful, fail to capture libraries' full impact on the lives of their users. The recent dominance of Gross Domestic Product (GDP) as the prevailing metric for policy and decision-making frames library value in exclusively economic terms. However, it is overreliance on economic measures like GDP in library assessment that leads to their undue underfunding. Meanwhile a tool like the Canadian Index of Wellbeing (CIW) is a credible alternative metric that shifts the focus from the purely economic toward additional facets of life. Developed through a broad cross-Canada consultation process, the CIW uses eight domains affecting wellbeing: community vitality, democratic engagement, education, environment, healthy populations, leisure and culture, living standards, and time use. Compared with the narrow economic focus of GDP, the CIW is a powerful tool to communicate the true value of public libraries and the impact they have on their users.
\end{abstract}

À travers l'histoire, les bibliothèques se sont débattues pour communiquer leur valeur de manière significative tant aux décideurs politiques qu'au grand public. Des mesures traditionnelles telles le nombre d'items dans une collection ou le nombre de prêts, quoique pratiques, ne permettent pas de comprendre le plein impact des bibliothèques sur la vie de leurs usagers. La dominance récente du produit intérieur brut (PIB) comme 
métrique prévalente pour la prise de décision et l'élaboration de politiques positionne la valeur de la bibliothèque en termes exclusivement économiques. Toutefois, c'est la confiance excessive liée aux mesures économiques telles le PIB pour l'évaluation des bibliothèques qui mène à leur sous-financement injustifié. Entre-temps, un outil comme le « Canadian Index of Wellbeing » (CIW) est une métrique alternative crédible qui change l'orientation d'un point de vue purement économique vers d'autres facettes de la vie. Développé grâce à une large consultation pancanadienne, le CIW utilise huit domaines touchant le bien-être : la vitalité communautaire, l'engagement démocratique, l'éducation, l'environnement, la santé des populations, le loisir et la culture, le niveau de vie et l'utilisation du temps. Comparé à l'orientation économique étroite du PIB, le CIW est un outil puissant pour communiquer la vraie valeur des bibliothèques publiques et l'impact qu'elles ont sur leurs usagers.

\section{Keywords / Mots-clés}

public libraries; wellbeing; Canadian Index of Wellbeing; library value; bibliothèques publiques, bien-être, Canadian Index of Wellbeing, valeur des bibliothèques

\section{Introduction}

Libraries have long struggled to communicate their value and contributions in terms that are meaningful to the general public-particularly non-library users-as well as to policy and budget decision makers. For decades libraries have primarily relied on the counting of "things"-physical items in the collection, circulation statistics, gate counts, reference questions, etc. - to tell their story. Increasingly, these inputs and outputs are also tallied against budgets to produce indicators like cost per use, dollars saved per visit, etc. The problem of assessing and communicating value is particularly vexing in public libraries. Academic libraries have a narrowed scope and mandate compared to public libraries, primarily serving the teaching, learning, and research needs of students and faculty. Special libraries, by their nature, also tend to serve a very specific segment of the population within a prescribed workplace or profession. This contrasts with the broad mandate facing public libraries: to be everyone's library for everything they might need. And while traditional measures like collection and circulation counts may be useful in some instances, they fail to address libraries' overall impact on citizens' lives.

Perhaps the most damaging development to efforts to assess and convey public library value is the increasing emphasis on Gross Domestic Product (GDP) in recent years. Originally intended as a measure of economic activity, GDP has become a proxy for progress and value that far outstrips its original intent. Roy Romanow, former Premier of Saskatchewan and head of the Royal Commission on the Future of Health Care in Canada, went so far as to call the GDP the "Gross Distortion of Prosperity" (2003) because it: a) only considers economic measures; b) assumes that economic progress benefits all equally; and 3) supposes that all economic activity is positive, while in fact spending in response to crime, climate change, illness, floods, and fires are all factors that drive the GDP up but certainly not positive indicators nor signs of progress. The oftunquestioned assumption that we can rely on economic activity as a success barometer "stems from the combination of neoconservative political ideology and neoliberal 
economic ideology" and "frames the discussion and choices regarding every public sphere activity, from libraries and education to national defense and environmental protection, as purely capitalist economic choices" (Jaeger et al, 2013, p. 373). Robert F. Kennedy famously highlighted the shortcomings of GDP when he stated,

[GDP] does not allow for the health of our children, the quality of their education or the joy of their play. It does not include the beauty of our poetry or the strength of our marriages, the intelligence of our public debate or the integrity of our public officials. It measures neither our wit nor our courage, neither our wisdom nor our learning, neither our compassion nor our devotion to our country, it measures everything in short, except that which makes life worthwhile. (1968, para. 22)

Economics alone simply cannot capture and convey the many facets of the human experience, nor the public goods (including libraries) that contribute to the richness of that which makes life worthwhile, as Kennedy put it. To value libraries solely according to contribution to GDP or return on investment fails to account for the value and impact of many library resources, services, and programs. The cumulative effect of policymakers assessing public libraries in economic terms through inadequate measures such as GDP is the fundamental undervaluing and systematic underfunding of these vital institutions.

In the face of the inadequacy of measures like GDP, libraries have become increasingly concerned about finding new ways to assess and communicate their value, particularly in the face of austerity budgets and a decline in traditional input/output statistics.

Although not an exhaustive list, some of the more well-known of these initiatives can be viewed as falling into the following categories: public sphere theory, economic development calculation, building of social capital, and knowledge creation. Widdersheim (2015) advocates for the use of public sphere theory as a framework to guide public library practice and research. He sees public sphere theory as offering a fresh way to conceptualize the political and social justice elements that he sees as core to the purpose of public libraries. Others, like Hancks (2012) and Mehra et al. (2017), focus on the economic development potential of libraries in calculating and conveying their value. Libraries, they argue, can develop small business support services and partner with local economic development agencies to increase perceptions of their value among taxpayers and decision makers. Libraries' potential to build social capital is another method of establishing and communicating value. Miller (2014) defines social capital as "links between people in society . . . which produce positive outcomes for the community as a whole" (p. 316). She, and others like Svendsen (2013) and Vårheim (2014), view this social capital creation as one of the public library's greatest contributions. Lankes, in his Atlas of New Librarianship, takes the view that the modern library's greatest impact is its role in knowledge creation, going so far as to declare that the field-wide "mission of libraries is to improve society through facilitating knowledge creation in their communities" (2011, p. 13). Each of these models for valuing the public library speaks to facets of library impact, but none provide a comprehensive picture, nor have they had much impact outside of the profession itself. 


\section{A New Approach-Wellbeing}

Over the past decade a new approach, focused on the concept of wellbeing, has emerged to supplement (and in some cases counter) the solely economic focus of the GDP. Several countries, including Italy, Germany, Wales, Scotland, Iceland, and New Zealand, have developed wellbeing or quality of life indices, and are looking to these measures to guide policy-making. The specific measures vary somewhat by country, but their overall goal is to improve citizen wellbeing by incorporating economic, health, social, cultural, and environmental goals into policy development. Germany, for example, developed twelve dimensions that fall within three broad categories: "our life," "our surroundings," and "our country" together capture the different but related personal, community, and national elements of wellbeing (Federal Government of Germany, 2017 , p. 15). The leaders of Iceland, Scotland, and New Zealand have joined forces in the Wellbeing Economy Governments (WeGo) to shift the focus in their countries from GDP to collective wellbeing (Trebeck, 2019). Each country in WeGo is implementing a unique approach to wellbeing, informed by local experts and national data. New Zealand has gone so far as to re-envision its budget process and created a Wellbeing Budget for 2019 and again in 2020. Budgets are structured to break down silos between government departments and agencies in order to focus on six priorities that emerged from data collected as part of the Living Standards Framework: taking mental health seriously, improving child wellbeing, supporting Māori and Pasifika aspirations, building a productive nation, transforming the economy, and investing in New Zealand (Government of New Zealand, 2019). Scotland, although it has not specifically developed a Wellbeing Budget, is starting to base policy and budget decisions on the wellness indicators underpinning their National Performance Framework. The Framework has 11 domains, including: children, communities, culture, economy, education, environment, fair work, health, human rights, poverty, and international presence (Scottish Government, n.d.). As First Minister Nicola Sturgeon notes, "Scotland is redefining what it means to be a successful nation by focusing on the broader wellbeing of the population as well as the GDP (Gross Domestic Product) of the country" (Scottish Government, 2019, para. 3). Thus, while each government's approach differs slightly, it is clear that their wellbeing agendas are being driven by similar concerns about the quality of life of their citizens.

\section{The Canadian Index of Wellbeing}

Canada was in fact one of the first countries to identify and track wellness measures. In 1999, the Atkinson Foundation enlisted experts to advise on creating a means of measuring the social, health, and economic wellbeing of Canadians. This work continued in subsequent years, with additional partners and experts contributing to the project and the development of wellbeing indicators. In 2011, the Canadian Index of Wellbeing (CIW) moved to its new home in the Faculty of Applied Health Sciences at the University of Waterloo (Canadian Index of Wellbeing, n.d.). The CIW has adopted the following as its working definition of wellness:

The presence of the highest possible quality of life in its full breadth of expression focused on but not necessarily exclusive to: good living standards, robust health, 
a sustainable environment, vital communities, an educated populace, balanced time use, high levels of democratic participation, and access to and participation in leisure and culture. (Canadian Index of Wellbeing, 2016, p. 11)

This definition, as well as the domains and indicators used in the CIW, were developed through a broad cross-Canada consultation process that included "national leaders and organizations, community groups, research experts, indicator users, and importantly, the Canadian public" (Canadian Index of Wellbeing, 2016, p. 14). Three rounds of consultation invited Canadians to share what wellbeing means to them in an effort to ensure that the resulting index reflected the lives and aspirations of real Canadians. The outcome was the emergence of eight domains that impact wellbeing, as shown in Figure 1. The domains are, of course, interrelated, with changes in one domain often impacting other domains as well.

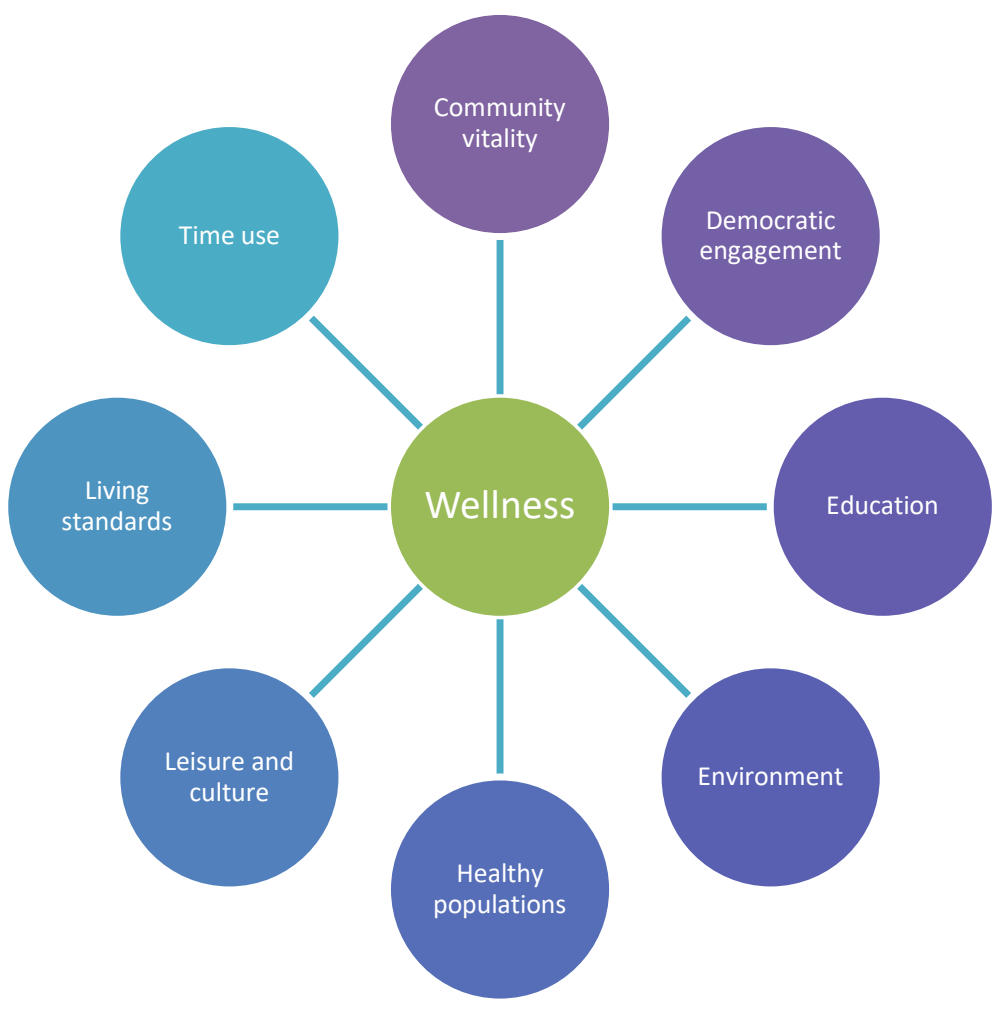

Figure 1. Eight domains from the Canadian Index of Wellbeing

The eight domains are further broken down into a set of 64 measureable indicators that are tracked using data from a range of sources, including Statistics Canada. These indicators have been updated in each of three CIW reports $(2011,2012$, and 2016) to provide a comprehensive overview of Canadians' wellbeing over this period of time. Additionally, the CIW continually evolves due to "an ongoing cycle of public engagement, consultation, and refinement" to "ensure that the Index is rooted in Canadian values, grounded in community experience, shaped by technical expertise, 
and responsive to emerging knowledge. The CIW is not a static measure" (Canadian Index of Wellbeing, 2016, p. 16).

In addition to the national wellbeing report, CIW has also worked with provincial and regional partners to create reports unique to their regions. To date, this includes the Ontario (2014), Nova Scotia (2018), and Saskatchewan (2019) Wellbeing reports, as well as reports for a number of smaller regions and cities. The reports have been used in varying ways in different jurisdictions. One is example is the Regional Municipality of Wood Buffalo, Alberta, which worked with CIW to develop its own dataset and is using it to understand the impacts of precipitous economic decline in the area between 2014 and 2019 on the wellbeing of residents. The analysis revealed three urgent issues: social isolation, mental health, and financial insecurity, and resulted in the prioritization of strategies to increase wellbeing on these fronts (Canadian Index of Wellbeing, 2019). Sector-specific approaches to using the CIW as a tool for prioritizing wellbeing include the Association of Ontario Health Centres $(\mathrm{AOHC})$, who are "exploring how they can apply the CIW to improve their efforts delivering primary health care in combination with health promotion and community development activities" (n.d., para. 5). Over $30 \mathrm{AOHC}$ facilities are applying CIW information in their work, including "assessing community needs, developing strategic plans, growing partnerships around shared priorities, measuring, evaluating, and improving programs and services, and raising awareness among decision-makers and the public about the need for better informed public policy focusing on health equity" (Association of Ontario Health Centres, n.d., para. 5). It is clear that the CIW indicators and data are beginning to inform the decisions and policies of jurisdictions across the country. The Government of Canada has also added "incorporating quality of life measurements" into the mandate letter of Mona Fortier, Minister of Middle Class Prosperity and Assistant Finance Minister, with government press releases explicitly citing New Zealand and Scotland as examples (Department of Finance, 2020). While the global pandemic may delay this effort, the federal government is certainly indicating that wellbeing will have a larger impact on budget and policy decisions in the future.

\section{Canadian Index of Wellbeing and Libraries}

National wellbeing documents, including the Canadian Index of Wellbeing, typically mention libraries in passing (if at all) as contributors to leisure and culture goals. Likewise, the library literature has had little to say about how libraries can embrace a focus on wellbeing indices and policies to assess and communicate the value of their resources, services, and programs. This is unfortunate because libraries contribute to all of the domains mentioned in the CIW, and this seems a powerful tool to engage decision makers and the wider public in the possibilities represented by their local library. There has been some research on the contributions of museums, as well as arts and heritage organizations, to wellbeing (Ander et al., 2011; Thomson \& Chatterjee, 2015 ) that provides inspiration for applying wellbeing measures to libraries. To date, efforts to engage with wellbeing in the museum literature have been based on generic indicators of wellbeing, drawn from the literature (Ander et al., 2011, p. 247). The library literature has described library contributions to specific elements of wellbeing, but there has been little work to bring all of this work together into a single, meaningful 
framework. It seems that aligning libraries with wellbeing goals could be particularly valuable in nations and regions with wellbeing indices, goals, or budgets, as these provide the opportunity to highlight the library in the context of widely known and accepted values. The Canadian Index of Wellbeing is one such framework that can be used to assess and communicate the value of libraries.

Table 1 lists the eight domains that comprise the Canadian Index of Wellbeing, describes each domain, outlines examples of possible library contributions to each domain, and then lists potential indicators that could be used to monitor library impacts on each domain. Two types of indicators are listed: 1) "CIW" indicators are pulled from the Canadian Index of Wellbeing and are those that are used to calculate progress on a large scale to which libraries might contribute; and 2) "Additional" are indicators that could be added to library efforts to measure and communicate their contributions to the eight wellness domains.

\section{Table 1}

Canadian Index of Wellbeing dimensions and library contributions

\begin{tabular}{|c|c|c|c|}
\hline Domains & Description $^{1}$ & $\underline{\text { Possible library contribution }}$ & $\frac{\text { Potential Indicators }}{(\text { CIW and Additional) }}$ \\
\hline $\begin{array}{l}\text { Community } \\
\text { vitality }\end{array}$ & $\begin{array}{l}\text { "vital } \\
\text { communities that } \\
\text { have strong, } \\
\text { active, and } \\
\text { inclusive } \\
\text { relationships } \\
\text { among people, } \\
\text { private, public, } \\
\text { and non- } \\
\text { governmental } \\
\text { organizations that } \\
\text { foster individual } \\
\text { and collective } \\
\text { wellbeing." }\end{array}$ & $\begin{array}{l}\text { - free or low cost } \\
\text { meeting space for } \\
\text { community groups } \\
\text { - } \begin{array}{l}\text { provider of community } \\
\text { programming }\end{array} \\
\text { - local collections/content, } \\
\text { including local history } \\
\text { resources }\end{array}$ & $\begin{array}{l}\text { - CIW: percentage of } \\
\text { population that reports } \\
\text { very or somewhat } \\
\text { strong sense of } \\
\text { belonging to } \\
\text { community } \\
\text { - CIW: percentage of } \\
\text { population that believe } \\
\text { that most or many } \\
\text { people can be trusted } \\
\text { - Additional: patron } \\
\text { participation in } \\
\text { community } \\
\text { programming } \\
\text { Additional: meeting } \\
\text { space use by } \\
\text { community groups }\end{array}$ \\
\hline
\end{tabular}

${ }^{1}$ As described in Canadian Index of Wellbeing, 2016, p. 15. 


\begin{tabular}{|c|c|c|c|}
\hline Domains & Description $^{1}$ & Possible library contribution & $\begin{array}{l}\text { Potential Indicators } \\
\text { (CIW and Additional) }\end{array}$ \\
\hline $\begin{array}{l}\text { Democratic } \\
\text { engagement }\end{array}$ & $\begin{array}{l}\text { "being involved in } \\
\text { advancing } \\
\text { democracy } \\
\text { through political } \\
\text { institutions, } \\
\text { organizations, } \\
\text { and activities." }\end{array}$ & $\begin{array}{l}\text { meeting space for local } \\
\text { candidates, committees, } \\
\text { organizations } \\
\text { programs on voting, } \\
\text { democracy (esp. for } \\
\text { young/new Canadians) } \\
\text { - access to quality } \\
\text { resources offering diverse } \\
\text { perspectives } \\
\text { programs to enhance } \\
\text { information fluency/critical } \\
\text { thinking skills }\end{array}$ & $\begin{array}{l}\text { - CIW: percentage of } \\
\text { voter turnout at federal } \\
\text { elections } \\
\text { CIW: gap in } \\
\text { percentage turnout } \\
\text { between older and } \\
\text { younger voters } \\
\text { - Additional: patron } \\
\text { participation in } \\
\text { programs on voting, } \\
\text { democracy } \\
\text { Additional: } \\
\text { partnerships with } \\
\text { organizations } \\
\text { promoting democracy/ } \\
\text { democratic } \\
\text { engagement }\end{array}$ \\
\hline Education & $\begin{array}{l}\text { "the systematic } \\
\text { instruction, } \\
\text { schooling, or } \\
\text { training given to } \\
\text { the young in } \\
\text { preparation for } \\
\text { the work of life, } \\
\text { and by extension, } \\
\text { similar instruction } \\
\text { or training } \\
\text { obtained in } \\
\text { adulthood." }\end{array}$ & 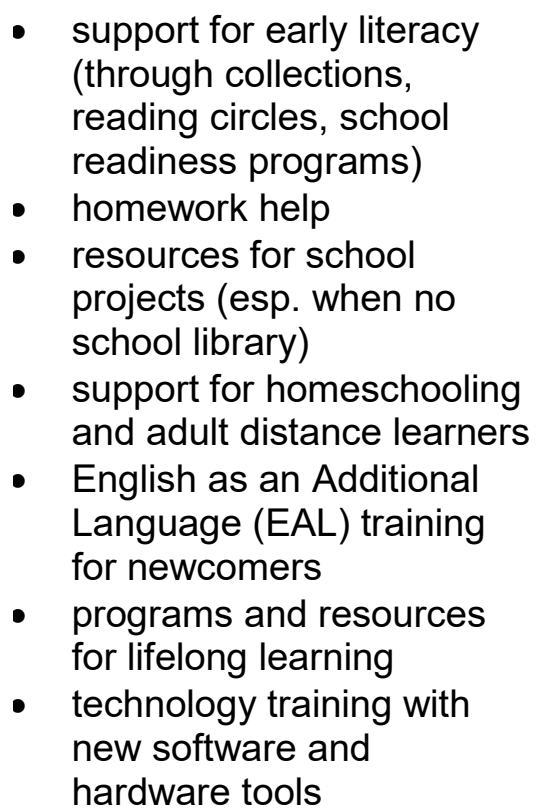 & $\begin{array}{l}\text { CIW: amount of time } \\
\text { spent in talk-based } \\
\text { activities with children } \\
\text { aged } 0 \text { to } 14 \text { years } \\
\text { CIW: percentage of } \\
\text { population aged } 25 \\
\text { and older participating } \\
\text { in education-related } \\
\text { activities } \\
\text { - Additional: patron } \\
\text { participation levels in } \\
\text { early literacy programs } \\
\text { Additional: number of } \\
\text { newcomers reaching } \\
\text { English proficiency } \\
\text { milestones }\end{array}$ \\
\hline
\end{tabular}




\begin{tabular}{|c|c|c|c|}
\hline Domains & Description $^{1}$ & Possible library contribution & $\begin{array}{l}\text { Potential Indicators } \\
\text { (CIW and Additional) }\end{array}$ \\
\hline Environment & $\begin{array}{l}\text { "the foundation } \\
\text { upon which } \\
\text { human societies } \\
\text { are built and the } \\
\text { source of our } \\
\text { sustained } \\
\text { wellbeing. On a } \\
\text { broader level, } \\
\text { environmental } \\
\text { protection } \\
\text { involves the } \\
\text { prevention of } \\
\text { waste and } \\
\text { damage while } \\
\text { revitalizing our } \\
\text { ecosystems and } \\
\text { working towards } \\
\text { the sustainability } \\
\text { of all our } \\
\text { resources." }\end{array}$ & $\begin{array}{l}\text { - } \text { serve as inspiration and } \\
\text { demonstration sites for } \\
\text { implementation of new } \\
\text { environmentally-friendly } \\
\text { building and maintenance } \\
\text { practices } \\
\text { - develop and/or host } \\
\text { programs on } \\
\text { environmental issues } \\
\text { reuse/sharing of physical } \\
\text { library collection }\end{array}$ & $\begin{array}{l}\text { CIW: absolute } \\
\text { greenhouse gas } \\
\text { emissions } \\
\text { - Additional: patron } \\
\text { participation in } \\
\text { environmental } \\
\text { programs } \\
\text { - Additional: } \\
\text { power/water/heat } \\
\text { savings from adoption } \\
\text { of new building } \\
\text { technologies }\end{array}$ \\
\hline $\begin{array}{l}\text { Healthy } \\
\text { populations }\end{array}$ & $\begin{array}{l}\text { "the physical, } \\
\text { mental, and } \\
\text { social wellbeing } \\
\text { of the population. } \\
\text { It examines life } \\
\text { expectancy, } \\
\text { lifestyle and } \\
\text { behaviours, and } \\
\text { the } \\
\text { circumstances } \\
\text { that influence } \\
\text { health such as } \\
\text { access to health } \\
\text { care." }\end{array}$ & $\begin{array}{l}\text { - assistance locating and } \\
\text { access to quality health } \\
\text { information } \\
\text { - } \quad \text { referral to community } \\
\text { health resources } \\
\text { - on-site health supports } \\
\text { (diabetes screening, } \\
\text { social worker) } \\
\text { - resources in accessible } \\
\text { formats (audio books, } \\
\text { screen readers, etc.) } \\
\text { safe, warm space for } \\
\text { those who need it }\end{array}$ & $\begin{array}{l}\text { - CIW: percentage of } \\
\text { population that rates } \\
\text { their overall health as } \\
\text { very good or excellent } \\
\text { CIW: percentage of } \\
\text { population that rates } \\
\text { their mental health as } \\
\text { very good or excellent } \\
\text { - Additional: successful } \\
\text { response to health } \\
\text { reference questions } \\
\text { - Additional: completed } \\
\text { referrals to community } \\
\text { health supports/ } \\
\text { partners }\end{array}$ \\
\hline
\end{tabular}




\begin{tabular}{|c|c|c|c|}
\hline Domains & Description $^{1}$ & Possible library contribution & $\frac{\text { Potential Indicators }}{\text { (CIW and Additional) }}$ \\
\hline $\begin{array}{l}\text { Leisure and } \\
\text { culture }\end{array}$ & $\begin{array}{l}\text { "how participating } \\
\text { in leisure and } \\
\text { cultural activities, } \\
\text { whether arts, } \\
\text { culture, or } \\
\text { recreation, } \\
\text { contributes to our } \\
\text { wellbeing as } \\
\text { individuals, to our } \\
\text { communities, and } \\
\text { to society as a } \\
\text { whole. The } \\
\text { myriad of } \\
\text { activities and } \\
\text { opportunities we } \\
\text { pursue and enjoy } \\
\text { benefit our } \\
\text { overall life } \\
\text { satisfaction and } \\
\text { quality of life." }\end{array}$ & $\begin{array}{l}\text { - free (or affordable) } \\
\text { cultural and leisure } \\
\text { activities and programs } \\
\text { for diverse populations } \\
\text { (children, families, } \\
\text { seniors) } \\
\text { - } \text { promoting/raising } \\
\text { awareness of Canadian } \\
\text { authors/creators } \\
\text { - } \text { access to physical and } \\
\text { virtual books, music, } \\
\text { movies, and other content } \\
\text { - multilingual collections } \\
\text { access to creative spaces } \\
\text { and technologies like } \\
\text { makerspaces, video } \\
\text { production tools, 3D } \\
\text { printers, performance } \\
\text { space } \\
\text { meeting space for local } \\
\text { cultural groups and } \\
\text { organizations }\end{array}$ & $\begin{array}{l}\text { CIW: average } \\
\text { percentage of time } \\
\text { spent on the previous } \\
\text { day in social leisure } \\
\text { activities } \\
\text { CIW: average } \\
\text { percentage of time } \\
\text { spent on the previous } \\
\text { day in arts and culture } \\
\text { activities } \\
\text { Additional: patron use } \\
\text { of creative } \\
\text { spaces/technologies } \\
\text { Additional: patron } \\
\text { engagement with } \\
\text { Canadian content } \\
\text { (collections, author } \\
\text { talks, etc.) }\end{array}$ \\
\hline
\end{tabular}




\begin{tabular}{|c|c|c|c|}
\hline Domains & Description $^{1}$ & Possible library contribution & $\begin{array}{l}\text { Potential Indicators } \\
\text { (CIW and Additional) }\end{array}$ \\
\hline $\begin{array}{l}\text { Living } \\
\text { standards }\end{array}$ & $\begin{array}{l}\text { “Canadians' } \\
\text { average and } \\
\text { median income } \\
\text { and wealth; } \\
\text { distribution of } \\
\text { income and } \\
\text { wealth including } \\
\text { poverty rates, } \\
\text { income } \\
\text { fluctuations and } \\
\text { volatility; and } \\
\text { economic } \\
\text { security, } \\
\text { including the } \\
\text { labour market, } \\
\text { and housing and } \\
\text { food security." }\end{array}$ & $\begin{array}{l}\text { - } \quad \text { career workshops } \\
\text { - } \quad \text { job fairs } \\
\text { - } \quad \text { equills upgrading computer } \\
\text { access, training, and } \\
\text { support } \\
\text { - } \quad \text { computer access and } \\
\text { assistance applying for } \\
\text { government support } \\
\text { programs/accessing } \\
\text { government } \\
\text { information/services } \\
\text { settlement } \\
\text { support/connecting new } \\
\text { Canadians with programs } \\
\text { and services } \\
\text { information and resources } \\
\text { for new businesses and } \\
\text { entrepreneurs }\end{array}$ & $\begin{array}{l}\text { - CIW: Gini coefficient } \\
\text { (income gap) } \\
\text { CIW: percentage of } \\
\text { households that are } \\
\text { moderately or severely } \\
\text { food insecure } \\
\text { - } \text { Additional: job } \\
\text { seeker/employer } \\
\text { matches at job fairs } \\
\text { - Additional: patron } \\
\text { completion of skills } \\
\text { development } \\
\text { programs }\end{array}$ \\
\hline Time use & $\begin{array}{l}\text { "how people } \\
\text { experience and } \\
\text { spend their time. } \\
\text { It examines how } \\
\text { the use of our } \\
\text { time affects } \\
\text { physical and } \\
\text { mental wellbeing, } \\
\text { individual and } \\
\text { family wellbeing, } \\
\text { and present and } \\
\text { future wellbeing." }\end{array}$ & $\begin{array}{l}\text { - } \quad \text { enriching programs } \\
\text { one-stop for many } \\
\text { resources, programs, } \\
\text { services } \\
\text { - } \quad \text { volunteer opportunities }\end{array}$ & $\begin{array}{l}\text { - CIW: percentage of } 15 \\
\text { to } 64 \text { years old } \\
\text { reporting high levels of } \\
\text { time pressure } \\
\text { - Additional: families } \\
\text { participating in library } \\
\text { programs } \\
\text { - Additional: use of } \\
\text { library for interest/ } \\
\text { quality of life purposes }\end{array}$ \\
\hline
\end{tabular}

Table 1 is not exhaustive but rather highlights some of the ways that library activities align with the eight domains of the CIW and provides some suggestions for indicators to capture and communicate these contributions.

The latest version of the CIW report also includes suggestions from experts in the eight domains for policy directions that could significantly improve the wellbeing of Canadians. Underpinning the recommendations is the realization that inequality is a major detractor from Canadian wellbeing:

A central theme that emerged from the discussions was inequality, not just in income, but in health, in access to community resources, and in opportunities for leisure and culture. In response, the group recommended policy directions that considered the impact on multiple domains of wellbeing-an innovative and 
integrated approach to policy that would create multiple benefits for Canadians and reaffirm their core values. (Canadian Index of Wellbeing, 2016, p. 67)

Interestingly, inequality not only detracted from the wellbeing of those Canadians who are personally experiencing poverty, food insecurity, etc., but this inequality impacted the wellbeing of all Canadians.

In addition to a recommendation to reduce inequality among Canadians through programs like a basic universal income and extending health and social benefits to lowincome Canadians, the policy directions suggested as having the potential to reduce equality and increase wellbeing include:

- build on the strength of the education domain and develop a Pan-Canadian education strategy

- focus on an "upstream" approach to health

- leverage the collaborative power of communities for social change

- provide universal access to leisure and culture

- improve the collection of social and environmental data (Canadian Index of Wellbeing, 2016, p. 67).

Again, as with the eight domains themselves, libraries are currently (or are positioned to be) key players in implementing these policy directives. At the most fundamental level, libraries aim to provide equal service to patrons, regardless of socioeconomic status or personal circumstances. In addition to free library cards and access, libraries typically make efforts to welcome all, regardless of housing security, accessibility requirements, etc. While there are undoubtedly places for improvement in the realization of this ideal, most libraries hold service equality as a core tenet.

Libraries also make important contributions to the realization of the other policy recommendations. One of the objectives of the education policy recommendation is to "increase the availability and affordability of formal and informal learning opportunities at all levels of education" (Canadian Index of Wellbeing, 2016, p. 70), which certainly aligns with availability of resources, and programs like early literacy, EAL, and adult skills development. The "upstream" approach to health requires "expand[ing] access by creating a comprehensive community-based network of health and social supports that enables people-especially those facing barriers to better health-to access its benefits where they live" (Canadian Index of Wellbeing, 2016, p. 73). Libraries are on the frontline of this community-based network of health and social supports, connecting patrons with information and community health supports, and providing first-level services, including blood pressure checks, access to mental health professionals, etc. Libraries are already far down the path and can be leaders in responding to the policy directive to "leverage the collaborative power of communities for social change" (Canadian Index of Wellbeing, 2016, p. 74). They regularly partner with community organizations, government agencies, non-profits, schools, and others in offering their programs and services. Libraries are also responding to the policy directive to "provide universal access to leisure and culture" by providing the free loan of books, video, music, etc., as well as offering a range of programs, including film theatres, book clubs, 
activity groups, etc. The policy directive to "improve the collection of social and environmental data" (Canadian Index of Wellbeing, 2016, p. 78) is instructive to libraries, as it encourages more targeted and effective use of data to assess and communicate our contributions to wellbeing.

\section{Limitations}

The Canadian Index of Wellbeing is the most comprehensive attempt to date to articulate and measure the many factors that contribute to the overall wellbeing of Canadians. It was created through extensive consultation with Canadians and is backed by rigorous data collection. That said, there are inevitably limitations resulting from the sheer enormity of the task of compiling a set of domains that reflect all Canadians. Some Canadians may find that some domains are less meaningful to them, or that facets of wellbeing important to them have been excluded. The CIW acknowledges limitations, for example, with respect to Indigenous people:

comprehensive data are lacking concerning Canada's Indigenous peoples. Many national surveys exclude persons living on reserves and in designated settlements within the provinces. They also frequently do not include the people living in Nunavut, Yukon, and the Northwest Territories. Consequently, their voices are rarely included in national profiles of Canadians. Given that Canada's Indigenous peoples face severe challenges to their health, living standards, and opportunities for quality education, their lack of representation in our data-and hence, our understanding-is unacceptable. (Canadian Index of Wellbeing, 2016, p. 79)

It is, however, reassuring to know that the CIW continues to conduct research in order to accurately reflect all Canadians. Future iterations of the CIW will be strengthened as additional voices and experiences are reflected in discussions of Canadian wellbeing.

\section{Conclusion}

The increasing focus on wellbeing in Canada and select other countries around the world has become particularly timely, given the changes wrought by the COVID-19 pandemic. Past research has highlighted that the impact of major world events is greater and more long-lasting in terms of the toll that it extracts on Canadians than that illustrated by the GDP alone. While the economy stumbled after the 2008 recession, "the economy has since recovered based on GDP" but the "wellbeing of Canadians took a significant step backwards, however, and has only begun to recover. From 1994 to 2014 , GDP grew by $38.0 \%$; yet, our wellbeing rose by only $9.9 \%$ " (Canadian Index of Wellbeing, 2016, p. 3). It seems likely that, as it did after 2008, the GDP will recover after the pandemic subsides, but it will be take much longer, and a more concerted effort, to rebuild after the multi-faceted damage inflicted on the wellbeing of Canadians. Virtually every domain in the Canadian Index of Wellbeing (community vitality, democratic engagement, education, environment, healthy populations, leisure and culture, living standards, and time use) has been impacted to some degree by the pandemic and measures enacted to protect against it. Considerable work lays ahead to 
return Canadian wellbeing to pre-pandemic levels and beyond. The Canadian Index of Wellbeing is an evolving, well-researched, and useful tool that provides a roadmap for Canadian governments, sectors, and institutions embarking on this work. Libraries are well-positioned to make major contributions to the wellbeing of fellow Canadians, given the alignment between their values and activities, and the domains and policy directions outlined in the Canadian Index of Wellbeing.

\section{Acknowledgements}

This paper discusses the Canadian Index of Wellbeing in order to extend its relevance to a pan-Canadian audience, but I was first introduced to the idea of wellness indicators by the Saskatchewan Index of Wellbeing, a joint initiative of Heritage Saskatchewan and the Community Initiatives Fund. Thanks to this partnership for inspiring this work and helping to make my province a better place to live.

\section{References}

Ander, E., Thomson, L., Noble, G., Lanceley, A., Menon, U., \& Chatterjee, H. (2011). Generic well-being outcomes: towards a conceptual framework for well-being outcomes in museums. Museum Management and Curatorship 26(3), 237-259.

Association of Ontario Health Centres. (n.d.). The Canadian Index of Wellbeing: A made-in-Canada tool to measure what matters. Shift the Conversation: Community Health and Wellbeing.

Canadian Index of Wellbeing. (n.d.). History.

Canadian Index of Wellbeing. (2016). How are Canadians really doing? The 2016 CIW national report. Waterloo, ON: Canadian Index of Wellbeing and University of Waterloo.

Canadian Index of Wellbeing. (2019). The Wellbeing of Wood Buffalo.

Department of Finance. Government of Canada. (2020, March 4). Minister Fortier discusses the importance of quality of life and well-being of Canadians in Victoria. Department of Finance Canada.

Federal Government of Germany. (2017). Government report on wellbeing in Germany. Berlin: Federal Press Office.

Government of New Zealand. (2019). The Wellbeing Budget 2019. The Treasury New Zealand. 
Hancks, J. (2012). Rural public libraries' role in community economic development. Public Library Quarterly 31(3), 220-36.

Jaeger, P. T., Gorham, U., Bertot, J. C. \& Sarin, L. C. (2013). Democracy, neutrality, and value demonstration in the age of austerity. The Library Quarterly: Information, Community, Policy 83(4), 368-382.

Kennedy, R. F. (1968). Remarks at the University of Kansas, March 18, 1968. John F. Kennedy Presidential Library and Museum.

Lankes, R. D. (2011). The Atlas of New Librarianship. Cambridge, MA; Chicago: MIT Press.

Mehra, B., Bishop, B. W., \& Partee II, R. P. (2017). Small business perspectives on the role of rural libraries in economic development. The Library Quarterly 87(1), 1735.

Miller, J. (2014). A comparative study of public libraries in Edinburgh and Copenhagen and their potential for social capital creation. Libri 64(4), 316-326.

Romanow, R. (2003, May 9). On the occasion of receiving The International Foundation's Public Service Award Ottawa, May 8, 2003. The Globe \& Mail.

Scottish Government. (n.d.). National performance framework.

Scottish Government. (2019). Health and wellbeing as fundamental as GDP.

Svendsen, G. L. H. (2013). Public libraries as breeding grounds for bonding, bridging and institutional social capital: The case of branch libraries in rural Denmark. Sociologia Ruralis 53(1), 52-73.

Thomson, L. J., \& Chatterjee, H. J. (2015). Measuring the impact of museum activities on well-being: developing the Museum Well-being Measures Toolkit. Museum Management and Curatorship 30(1), 44-62.

Trebeck, K. (2019). Here we go: First Wellbeing Economic Governments policy lab underway. Wellbeing Economy Alliance.

Vårheim, A. (2014). Trust in libraries and trust in most people: Social capital creation in the public library. The Library Quarterly 84(3), 258-77.

Widdersheim, M. M. (2015). Governance, legitimation, commons: A public sphere framework and research agenda for the public library sector. Libri 65(4), 237-245. 